УДК 657.1.014.134

Жураковська Ірина,

кандидат економічних наук, доцент, Луцький національний технічний університет, кафедра обліку і аудиту, м. Луцьк, ORCID ID 0000-0001-9803-5874, e-mail: zhurakovska@ukr.net

https://doi.org/10.29038/2786-4618-2021-04-56-66

\title{
ПРОФЕСІЙНА КОМПЕТЕНТНІСТЬ БУХГАЛТЕРІВ В УКРАЇНІ: ЯК ПЕРЕВІРИТИ?
}

Метою дослідження $є$ оцінка компетентності бухгалтерів в Україні шляхом підтвердження чи спростування двох гіпотез. Перша: професійний досвід бухгалтера позитивно впливає на професійну компетентність бухгалтера, а отже і на стан обліку, для оцінки компетентності можна орієнтуватись на професійний стаж роботи. Друга: на великих підприємствах працюють більш компетентні головні бухгалтери, так як робота потребує більше знань і навчання. Обидві гіпотези підтверджено з єдиним зауваженням, що у бухгалтерів зі стажем понад 41 рік показники різко погіршуються. Результати досліджень грунтуються на оцінці компетентності головних бухгалтерів акціонерних товариств. Оцінка проводилась за допомогою показника «кількість негативних результатів податкових перевірок та судових справ 3 контролюючими органами». Аналізувалась залежність показника від професійного досвіду бухгалтера, розміру підприємства, наявності в структурі статутного капіталу іноземних власників. Джерелом даних для аналізу стала звітність 334 акціонерних товариств України, які зобов'язані розкривати дані про освіту, досвід, вік головного бухгалтера. Ці дані були доповнені відомостями з бази даних ДПС по коду СДРПОУ та Реєстру судових рішень за пошуком по ЄДРПОУ. Встановлено, що аналізований показник на мікропідприємствах та підприємствах на аутсорсінгу $€$ найгіршим. Наведені результати досліджень доводять необхідність впровадження вітчизняної сертифікації 3 оптимальним бюджетом для забезпечення якості облікової інформації.

Ключові слова: бухгалтер, компетентність бухгалтера, результати податкових перевірок, аутсорсінг, акціонерне товариство.

Жураковская Ирина, кандидат экономических наук, доцент, Луцкий национальный технический университет, кафедра учета и аудита, г. Луцк

\section{ПРОФЕССИОНАЛЬНАЯ КОМПЕТЕНТНОСТЬ БУХГАЛТЕРОВ В УКРАИНЕ: КАК ПРОВЕРИТЬ?}

Целью исследования является оценка компетентности бухгалтеров в Украине путем подтверждения или опровержения двух гипотез. Первая: профессиональный опыт бухгалтера оказывает положительное влияние на профессиональную компетентность бухгалтера, а следовательно и на состояние учета, для оценки компетентности можно ориентироваться на профессиональный стаж работы. Вторая: на крупных предприятиях работают более компетентные главные бухгалтеры, так как работа требует больше знаний и обучения. Обе гипотезы подтверждены с единственным замечанием, что у бухгалтеров со стажем более 41 года показатели резко ухудшаются. Результаты исследований основываются на оценке компетентности основных бухгалтеров акционерных обществ. Оценка производилась с помощью показателя «количество негативных результатов налоговых проверок и судебных дел с контролирующими органами». Анализировалась зависимость показателя от профессионального опыта бухгалтера, размера предприятия, наличия в структуре уставного капитала иностранных собственников. Источником данных для анализа стала отчетность 334 акционерных обществ Украины, которые обязаны раскрывать данные об образовании, опыте, 
возрасте главного бухгалтера. Эти данные были дополнены сведениями из базы данных ГНС по коду ЕГРПОУ и Реестра судебных решений по поиску по ЕГРПОУ. Установлено, что анализируемый показатель на микропредприятиях и предприятиях на аутсорсинге является самым плохим. Приведенные результаты исследований доказывают необходимость внедрения отечественной сертификации с оптимальным бюджетом для обеспечения качества учетной информации.

Ключевые слова: бухгалтер, компетентность бухгалтера, результаты налоговых проверок, аутсорсинг, акционерное общество.

Zhurakovska Iryna, Phd in economic sciences, docent, Lutsk National Technical University, Department of Accounting and Audit,

Lutsk

\section{PROFESSIONAL COMPETENCE OF ACCOUNTANTS IN UKRAINE: HOW TO CHECK?}

Introduction. The competence of accountants affects not only the efficiency of an individual enterprise. This is a socially significant profession on which the formation of information for decision-making at the state level also depends. In Ukraine, there is a mandatory certification of auditing and accountants of financial institutions. The competence of the accountants of ordinary enterprises is not monitored in any way. It is important to study the competence of accountants to substantiate the importance of professional development of accountants at the state level.

Purpose of the article. The aim of the study is to assess the competence of chief accountants in Ukraine by confirming or refuting two hypotheses. First: the professional experience of an accountant has a positive effect on the professional competence of an accountant, and therefore on the state of accounting; to assess competence, one can focus on professional work experience. Second, large enterprises employ more competent chief accountants, as the work requires more knowledge and training.

Results. Both hypotheses were confirmed with the only remark that the indicators of accountants with more than 41 years of experience sharply deteriorate. The research results are based on the assessment of the competence of the main accountants of joint stock companies. The assessment was carried out using the indicator "the number of negative results of tax audits and court cases with regulatory authorities". Analyzed the dependence of the indicator on the professional experience of the accountant, the size of the enterprise, the presence of foreign owners in the structure of the authorized capital. The source of data for the analysis was the reporting of 334 joint-stock companies of Ukraine, which are required to disclose data on the education, experience, age of the chief accountant. These data were supplemented with information from the STS database and the Register of court decisions. It was found that the analyzed indicator in micro and outsourcing enterprises is the worst.

Conclusions. The above research results prove the need for the introduction of domestic certification, advanced training with an optimal budget to ensure the quality of accounting information.

Key words: accountant, accountant's competence, results of tax audits, outsourcing, joint-stock company.

Постановка проблеми. Професія бухгалтера $\epsilon$ суспільно значимою, адже забезпечує формування інформації для прийняття управлінських рішень як на мікро-, так і на макро- рівні. Якість такої інформації залежить від професійної компетентності бухгалтера. Але яким чином вона контролюється в Україні? Практика законодавчих змін в сфері бухгалтерського обліку свідчить, що наявність диплому вищої освіти з обліку не гарантує, що бухгалтер через10 років після закінчення університету має відповідні знання для роботи по спеціальності.

В Україні давно на теоретичному рівні розроблено трирівневу систему професійної сертифікації бухгалтерів, яку так і не було реалізовано на практиці. Система передбачає «базовий рівень - що базується на засвоєнні професійних дисциплін фахової підготовки освітньо-кваліфікаційного рівня магістр; професійний (загальний) - в основу якого покладено професійну підготовку, що визнається на рівні об'єднання професійних організацій; професійний (спеціальний) - найвищий рівень 
сертифікації (аудитор) з визначенням відповідної спеціалізації, визначається Аудиторською палатою України та державними регуляторами» [1]. Якщо перший і третій рівні працюють, то другий рівень законодавчо не визначено і оцінка якості роботи бухгалтерів проводиться самим роботодавцем на підставі співбесіди, тестування, результатів податкової перевірки, направлення на сертифікацію, зазначення певних вимог в резюме і т.д. Але наскільки діюча система в Україні $\epsilon$ ефективною?

Аналіз останніх досліджень і публікацій. Необхідність розробки законодавчого підгрунтя для оцінки професійних компетентносте бухгалтерів наголошували у своїх дослідженнях В.М. Жук [2], M.I. Бондар [1], М.М. Шигун [1] та ін. Ними ж запропоновано систему сертифікації. Теоретичні напрацювання щодо компетенцій бухгалтерів розкрито в працях І. Плікус [4], Т. Жукової [4], О. Осадчої [4] та ін. Більш практичні дослідження щодо компетентносте бухгалтерів в Україні проведено В. Рожелюк [6]. Проте вони стосувались переробної галузі агропромислового комплексу. Погляд на кваліфікацію бухгалтера крізь призму запитів роботодавців досліджували Н. Царук [7] Н. Мукан [3], О. Мукан [3], Р. Драган [3] та ін. Проте дослідження не відображають реальних демографічних даних щодо головних бухгалтерів в Україні.

Методика досліджень компетентносте бухгалтерів, яка грунтується на реальних даних щодо вікової, статевої структури, освіти, стажу в різних країнах розкрита в дослідженнях іноземних науковців $[10 ; 11 ; 12]$

Виділення невирішених раніше частин загальної проблеми.

Зважаючи на обмеженість даних в Україні нами сформовано власний підхід до оцінки компетентностей, який хоч і не є достатньо точним, проте дає загальне уявлення про стан справ щодо професійної компетентності бухгалтерів.

Метою дослідження $є$ оцінка компетентності бухгалтерів в Україні шляхом підтвердження чи спростування наступних гіпотез:

1) Професійний досвід бухгалтера позитивно впливати на професійну компетентність бухгалтера, а отже і на стан обліку. Через відсутність обов'язкової сертифікації роботи бухгалтера, припускаємо, що для оцінки компетентності можна орієнтуватись на професійний стаж роботи.

2) На великих підприємствах працюють більш компетентні головні бухгалтери, так як робота потребує більше знань і навчання.

Виклад основного матеріалу. Для оцінки компетентності нами зроблено акцент на результатах податкових перевірок і податкові борги підприємств. В більшості випадків податкові штрафи - це невміла робота бухгалтерії. Для зібрання необхідних даних щодо оцінки компетентності бухгалтерів нами було зроблено пошук відкритих даних про характеристику посад головного бухгалтера на підприємствах України. Пошук був полегшений тим, що згідно Рішення Національної комісії цінних паперів і фондового ринку Про затвердження Положення про розкриття інформації емітентами цінних паперів від 03.12.2013 №2826 в річній звітності акціонерні товариства повинні розкривати «інформацію про органи управління, посадових осіб, засновників та/або учасників емітента. Інформація про посадових осіб емітента має містити дані щодо освіти та стажу роботи посадових осіб емітента...» [5].

Шляхом опрацювання даних відкритого ресурсу фінансової звітності SMIDA нами зібрано базу даних про 334 акціонерних товариства України за 20208 рік з наступними показниками:

- назва підприємства;

- вид діяльності;

- показники для оцінки розміру підприємства (кількість працівників, рядок 1300 Балансу, рядок 2000 Звіту про фінансові результати)

- структура власності (українець, іноземець)

- освіта, стаж роботи, рік народження, дата прийняття на роботу, загальний стаж роботи за професією головного бухгалтера. 
Зібрана база даних підприємств була доповнена інформацією 3 відкритих реєстрів Державної податкової служби (ДПС) «Дізнайся більше про свого бізнес-партнера» щодо наявності податкових боргів та Реєстру судових рішень щодо наявності судових спорів, в тому числі з контролюючими органами.

До вибірки увійшли підприємства різних видів діяльності та різних розмірів, з різноманітною податковою історією та судовими справами.

Перелік досліджуваних підприємств за видами діяльності наведено в табл.1

Таблиия 1

Групування вибірки досліджуваних акціонерних товариств за видами діяльності (КВЕД) у 2020 році

\begin{tabular}{|c|c|c|c|}
\hline $\begin{array}{l}\text { № } \\
\text { 3/ח }\end{array}$ & Виді діяльності & $\begin{array}{c}\text { Кількість, } \\
\text { од }\end{array}$ & $\begin{array}{l}\text { Питома вага } \\
\text { у вибірці, \% }\end{array}$ \\
\hline 1. & Сільське господарство, лісове господарство та рибне господарство & 23 & 6,9 \\
\hline 2. & Добувна промисловість і розроблення кар'єрів & 16 & 4,8 \\
\hline 3. & Переробна промисловість & 96 & 28,7 \\
\hline 4. & Постачання електроенергії, газу, пари та кондиційованого повітря & 5 & 1,5 \\
\hline 5. & Водопостачання; каналізація, поводження з відходами & 2 & 0,6 \\
\hline 6. & Будівництво & 21 & 6,3 \\
\hline 7. & $\begin{array}{l}\text { Оптова та роздрібна торгівля; ремонт автотранспортних засобів і } \\
\text { мотоциклів }\end{array}$ & 21 & 6,3 \\
\hline 8. & $\begin{array}{l}\text { Транспорт, складське господарство, поштова та кур'єрська } \\
\text { діяльність }\end{array}$ & 11 & 3,3 \\
\hline 9. & Тимчасове розміщування й організація харчування & 4 & 1,2 \\
\hline 10. & Інформація та телекомунікації & 9 & 2,7 \\
\hline 11. & Фінансова та страхова діяльність & 35 & 10,5 \\
\hline 12. & Операції з нерухомим майном & 44 & 13,2 \\
\hline 13. & Професійна, наукова та технічна діяльність & 14 & 4,2 \\
\hline 14. & $\begin{array}{lcccc}\text { Діяльність } & \text { у } \\
\text { обслуговування } & \text { сфері } & \text { адміністративного } & \text { та } & \text { допоміжного }\end{array}$ & 2 & 0,6 \\
\hline 15. & Освіта & 2 & 0,6 \\
\hline 16. & Надання інших видів послуг & 29 & 8,7 \\
\hline & Разом & 334 & 100 \\
\hline
\end{tabular}

Джерело: Власна розробка автора

В досліджуваній сукупності представлено практично всі групи КВЕД, проте найбільша кількість (понад 28\%) це підприємства переробної промисловості, фінансова і страхова діяльність (10,5\%), операції з нерухомим майном (13,2\%). Групування досліджуваної вибірки підприємств за розмірами наведено в табл. 2. 
Групування вибірки досліджуваних акціонерних товариств за розміром у 2020 році

\begin{tabular}{|c|c|c|c|c|c|c|}
\hline \multirow[t]{2}{*}{$\begin{array}{l}\text { № } \\
\text { 3/ח }\end{array}$} & \multirow[t]{2}{*}{$\begin{array}{c}\text { Найменування } \\
\text { показника }\end{array}$} & \multirow[t]{2}{*}{$\begin{array}{c}\text { Оди- } \\
\text { ниця } \\
\text { виміру }\end{array}$} & \multicolumn{4}{|c|}{$\begin{array}{c}\text { Розмірна категорія підприємства у } 2020 \text { році згідно ч. } 2 \text { ст. } 2 \text { Закону } \\
\text { України «Про бухгалтерський облік та фінансову звітність в Україні» } \\
\text { від 16.07.1999 № 996-XIV }\end{array}$} \\
\hline & & & Мікро & Мале & Середнє & Велике \\
\hline \multirow[b]{2}{*}{1} & \multirow{2}{*}{$\begin{array}{l}\text { Балансова } \\
\text { вартість } \\
\text { активів, } \\
\text { євро/грн }\end{array}$} & євро & До 350000 & До 4000000 & До 20000000 & Більше 20000000 \\
\hline & & грн & До 10776500 & До 123160000 & До 615800000 & Більше 615800000 \\
\hline \multirow{2}{*}{2} & \multirow{2}{*}{$\begin{array}{l}\text { Чистий дохід } \\
\text { від реалізації, } \\
\epsilon в р о / г р н\end{array}$} & євро & До 700000 & До 8000000 & До 40000000 & Більше 40000000 \\
\hline & & грн & До 21553000 & До 246320000 & До 1231600000 & Більше 1231600000 \\
\hline 3 & $\begin{array}{l}\text { Середня } \\
\text { кількість } \\
\text { працівників } \\
\end{array}$ & чол. & До 10 & До 50 & До 250 & Більше 250 \\
\hline 4 & $\begin{array}{l}\text { Кількість } \\
\text { підприємств } \quad \text { у } \\
\text { вибірці }\end{array}$ & од. & 115 & 152 & 32 & 35 \\
\hline 5 & $\begin{array}{lll}\text { Питома вага } \\
\text { вибірці }\end{array}$ & $\%$ & 34,43 & 45,51 & 9,58 & 10,48 \\
\hline
\end{tabular}

Джерело: Власна розробка автора

У нашому дослідженні переважають малі (понад 45\%) та мікро (понад 34\%) підприємства, що презентує структуру бізнесу в цілому по Україні. На великі підприємства припадає близько $10 \%$ від загальної їх кількості у вибірці.

Розподіл підприємств щодо їх податкової історії і наявності судових справ за всю історію підприємства наведено в табл.3.

Таблиия 3

Групування вибірки досліджуваних акціонерних товариств за податковою історією і судовими спорами у 2020 році

\begin{tabular}{|c|l|r|r|}
\hline $\begin{array}{c}\text { № } \\
\text { 3/п }\end{array}$ & \multicolumn{1}{|c|}{ Показник } & $\begin{array}{c}\text { Кількість, } \\
\text { од }\end{array}$ & $\begin{array}{c}\text { Питома вага у } \\
\text { вибірці, № }\end{array}$ \\
\hline 1 & Не має податкового боргу і спорів 3 податковою & 250 & 74,85 \\
\hline 2 & $\begin{array}{l}\text { Наявний податковий борг та/ або судові справи 3 } \\
\text { контролюючими органами }\end{array}$ & 84 & 25,15 \\
\hline 3 & Чисельність судових справ в реєстрі судових рішень до 100 & 215 & 64,37 \\
\hline 4 & Чисельність судових справ в реєстрі судових рішень до 101 & 119 & 35,63 \\
\hline
\end{tabular}

Джерело: Власна розробка автора

Крім того цікавим з точки зору досліджень виявився факт, що з 334 підприємств тільки 245 мають $100 \%$ власників Українців, у решти певна часка належить іноземним компаніям та громадянам. Розподіл підприємств за наявності в у складі власників нерезидентів наведено в табл. 4

Щодо географії розташування, то більшість підприємств представляють всю Україну. Однак 50\% належать Київській і Львівській області.

Наші дані дозволяють отримати узагальнені результати, так як до уваги не брався досвід роботи на конкретному підприємстві та наявність судових спорів та рішень за час роботи конкретного бухгалтера і т.д. Проте отримані показники дозволять все ж таки отримати певні результати щодо компетентності. 
Групування вибірки досліджуваних акціонерних товариств за країною власником/співвласником досліджуваних підприсмств вибірки у 2020 році

\begin{tabular}{|c|l|l|l|}
\hline $\begin{array}{c}\text { № } \\
\text { 3/п }\end{array}$ & $\begin{array}{l}\text { Країна - власник/співвласник досліджуваних } \\
\text { акціонерних товариств }\end{array}$ & & \\
\hline 1 & Україна $100 \%$ & 245,00 & 73,35 \\
\hline 2 & Кіпр & 31,00 & 9,28 \\
\hline 3 & Великобританія & 16,00 & 4,79 \\
\hline 4 & Сейшельські острови & 3,00 & 0,90 \\
\hline 5 & Нідерланди & 4,00 & 1,20 \\
\hline 6 & Німеччина & 2,00 & 0,60 \\
\hline 7 & Віргінські острови & 6,00 & 1,80 \\
\hline 8 & Канада & 2,00 & 0,60 \\
\hline 9 & Інші & 25,00 & 7,49 \\
\hline & Разом & 334 & \\
\hline
\end{tabular}

Джерело: Власна розробка автора

Для підтвердження чи спростування першої гіпотези нами порівняно досвід бухгалтерів $і$ податкову історію підприємств.

Для аналізу впливу досвіду роботи бухгалтера на податкову історію і господарські спори досліджувані підприємства бути згруповані за професійним досвідом бухгалтерів від 0 до 41 і більше років 3 кроком у 5 років. Окремою групою виділено підприємства, в яких відсутні головні бухгалтери і обслуговуються на аутсорсінгу. Результати наведено в табл. 5.

Таблиия 5

Групування вибірки досліджуваних акціонерних товариств за роками професійного досвіду бухгалтерів і податковою історісю у 2020 році

\begin{tabular}{|l|l|l|l|l|l|}
\hline $\begin{array}{c}\text { № } \\
3 / \text { п }\end{array}$ & $\begin{array}{c}\text { досвід роботи, } \\
\text { років }\end{array}$ & $\begin{array}{c}\text { кількість } \\
\text { підприємств, } \\
\text { од }\end{array}$ & $\begin{array}{l}\text { Питома вага } \\
\text { у вибірці, \% }\end{array}$ & $\begin{array}{c}\text { податкова історія } \\
\text { (наявність } \\
\text { податкових } \\
\text { боргів), од }\end{array}$ & $\begin{array}{c}\text { наявність } \\
\text { судових } \\
\text { рішень, од }\end{array}$ \\
\hline 1 & $0-5$ & 13 & 3,89 & 4 & 176 \\
\hline 2 & $6-10$ & 15 & 4,49 & 4 & 398 \\
\hline 3 & $11-15$ & 37 & 11,08 & 6 & 2636 \\
\hline 4 & $16-20$ & 49 & 14,67 & 11 & 9484 \\
\hline 5 & $21-25$ & 54 & 16,17 & 9 & 3614 \\
\hline 6 & $26-30$ & 34 & 10,18 & 5 & 2518 \\
\hline 7 & $31-35$ & 40 & 11,98 & 6 & 4254 \\
\hline 8 & $36-40$ & 29 & 8,68 & 7 & 4961 \\
\hline 9 & 41 і більше & 27 & 8,08 & 6 & 934 \\
\hline 10 & аутсорсінг & 36 & 10,78 & 10 & \\
\hline & & 334 & & & \\
\hline
\end{tabular}

Джерело: Власна розробка автора

Результати досліджень показують, що понад 10\% підприємств обслуговуються на аутсорсінгу, але більше $31 \%$ підприємств - це фахівці $з$ досвідом 16-25 років, тобто їх вік від 40 до 55 років. Для аналізу показників податкових боргів та судових справ в середньому по кожній групі нами пораховано середні показники в табл. 6. 
Групування вибірки досліджуваних акціонерних товариств за роками професійного досвіду бухгалтерів і податковою історісю (середні показники) у 2020 році

\begin{tabular}{|l|l|l|l|l|l|}
\hline $\begin{array}{c}\text { № } \\
\text { 3/п }\end{array}$ & $\begin{array}{c}\text { досвід } \\
\text { роботи, } \\
\text { років }\end{array}$ & $\begin{array}{c}\text { кількість } \\
\text { підприємств, } \\
\text { од }\end{array}$ & $\begin{array}{c}\text { податкова } \\
\text { історія (середній } \\
\text { показник по } \\
\text { групі }\end{array}$ & $\begin{array}{c}\text { наявність судових } \\
\text { рішень (середній } \\
\text { показник по групі) }\end{array}$ & $\begin{array}{c}\text { частка } \\
\text { українського } \\
\text { капіталу,\% }\end{array}$ \\
\hline 1 & $0-5$ & 13 & 0,30 & 13,5 & 68,0 \\
\hline 2 & $6-10$ & 15 & 0,26 & 26,5 & 68,8 \\
\hline 3 & $11-15$ & 37 & 0,16 & 71,2 & 58,2 \\
\hline 4 & $16-20$ & 49 & 0,22 & 193,5 & 67,8 \\
\hline 5 & $21-25$ & 54 & 0,16 & 66,9 & 64,3 \\
\hline 6 & $26-30$ & 34 & 0,14 & 74,0 & 69,1 \\
\hline 7 & $31-35$ & 40 & 0,15 & 106,3 & 73,9 \\
\hline 8 & $36-40$ & 29 & 0,24 & 67,6 & 54,9 \\
\hline 9 & 41 і більше & 27 & 0,22 & 169,7 & 79,4 \\
\hline 10 & аутсорсінг & 36 & 0,27 & 25,9 & \\
\hline & Разом & 334 & & & \\
\hline
\end{tabular}

Джерело: Власна розробка автора

Отримані результати по вибраних 334 підприємствах України свідчать, що найбільше податкових боргів і спорів в групі бухгалтерів 3 досвідом 0-5 років (показник 0,30) а також у підприємств, які на аутсорсінгу (показник 0,27). Останній схиляє до думки про незадовільну якість аутсорсінгу. Наші очікування сутності цих послуг полягали в тому, що в цій групі мають бути найкращі показники. У підприємств, де досвід головного бухгалтера 6-10 років, розрахований середні показник податкових боргів становить 0,26 . В цих результатах можна прослідувати певну логіку зважаючи на те, що досвід податкових перевірок позитивно впливає на проходження наступних. Щодо судових рішень, то чітко виділяється група підприємств, де стаж бухгалтерів понад 41 рік, їх вік більше 60 років та група підприємств з віком 16-20 років. Ми розуміємо, що частина судових спорів не має відношення до компетентності бухгалтера, тому він не $є$ головним у нашому дослідженні. Проте, якщо одночасно звернути увагу на середній показник податкового боргу і судових рішень, то група підприємств, де досвід бухгалтерів понад 41 рік виглядають найбільш ризикованими. Це бухгалтери з віком понад 63 роки. І таких підприємств $8 \%$ у нашій вибірці.

Якщо аналізувати групи підприємств за частками власників-резидентів, то можемо побачити, що у всіх групах частка українців приблизно однакова - від 58\% до 73\%. Прослідковується тільки чітко, що на аутсорсінгу перебувають переважно підприємства, власниками яких є громадяни України.

Для підтвердження другої гіпотези нами груповано досліджувані підприємства за розміром на мікро, малі, середні та великі і визначено середній стаж головних бухгалтерів у кожній групі, що представлена в табл.7.

Таблиия 7

Групування вибірки досліджуваних акціонерних товариств

за роками професійного досвіду бухгалтерів і розміром підприсмства у 2020 році

\begin{tabular}{|c|c|c|c|c|c|c|}
\hline \multirow{2}{*}{$\begin{array}{l}\text { № } \\
\text { 3/ח }\end{array}$} & \multirow{2}{*}{$\begin{array}{c}\text { Найменування } \\
\text { показника }\end{array}$} & \multicolumn{4}{|c|}{ Категорія підприємств за розміром } & \multirow{2}{*}{ Разом } \\
\hline & & Мікро & Мале & Середне & Велике & \\
\hline 1 & Кількість, од. & 115 & 152 & 32 & 35 & 334 \\
\hline 2 & середній стаж, років & 18,2 & 21,9 & 20,5 & 26,4 & \\
\hline 3 & на аутсорсінгу, од & 23 & 9 & 3 & 1 & 36 \\
\hline 4 & \% підприємств за розміром на аутсорсінгу & 20,0 & 5,9 & 9,3 & 2,8 & \\
\hline 5 & Середня частка українського капіталу, \% & 80,1 & 66,8 & 59,2 & 27,5 & \\
\hline
\end{tabular}

Джерело: Власна розробка автора 
Ми отримали підтвердження другій гіпотезі, адже середній стаж головного бухгалтера на великому підприємстві понад 26 років, коли на мікропідприємстві біля 18. Поряд 3 цим виявилось, що частка українського капіталу у досліджуваних підприємствах зменшується з ростом розміру підприємства, що представлено на рис.1. Підкреслимо, що підприємства були відібрані випадковим шляхом, отже можна говорити, що це загальноукраїнська тенденція.

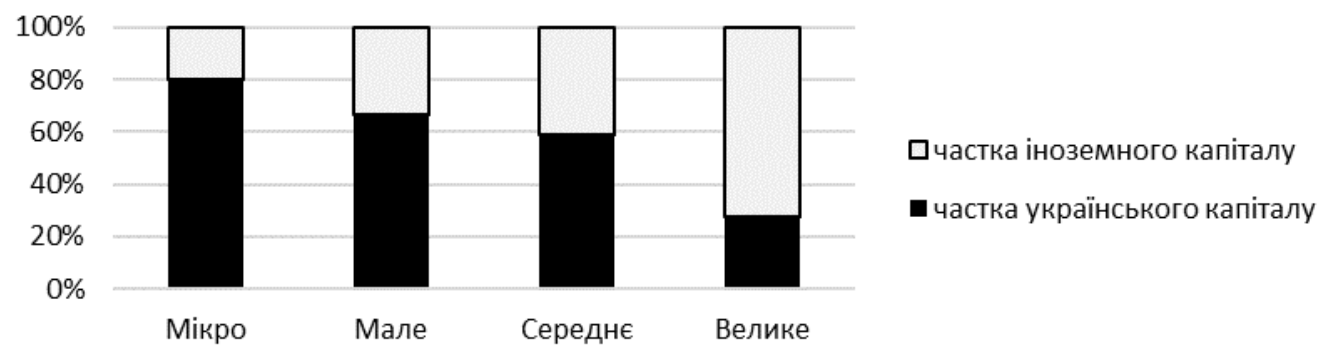

Рис.1. Відсоток украӥнського капіталу у статуті 334 досліджуваних акціонерних товариств України у 2020 році

Джерело: Власна розробка автора

Якщо в мікропідприємствах середня частка власників українців понад 59\%, то у великих тільки $26 \%$, одночасно досвід бухгалтерів є більшим і відсоток підприємств на аутсорсінгу зменшується (рис.2).

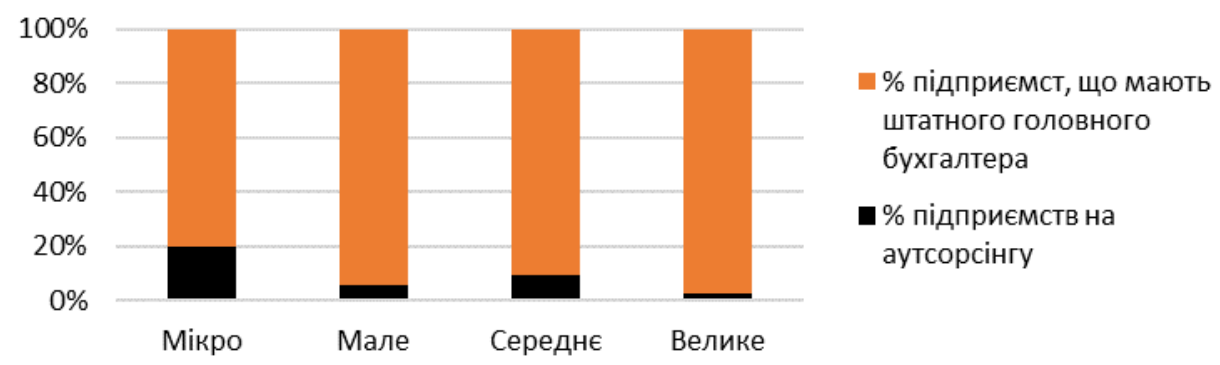

Рис.2. Частка штатних головних бухгалтерів на 334 досліджуваних акиіонерних товариствах

Джерело: Власна розробка автора

Украӥни у 2020 рочі

Висновки та пропозиції. Зібрані нами дані підтверджують гіпотези, що: 1) професійний досвід бухгалтерів має вплив на компетентність, яку ми оцінювали за результатами перевірок контролюючих органів (судові справи, податкові борги); 2) на великих підприємствах, де облік складний, працюють фахівці з більшим стажем. Однак, коли досвід більше 41 року, картина кардинально змінюється. В ході нашого дослідження виявлено цікаві факти про аутсорсінг. На підприємствах, де він використовується, оцінювана нами компетентність за результатами податкових перевірок $€$ низькою, крім того на аутсорсінгу переважно мікропідприємства.

Яким ще чином убезпечити підприємства від неякісного аутсорсінгу та некваліфікованих бухгалтерів? Для акціонерних товариств, які були об'єктом дослідження, якість обліку контролюється аудиторами. Звітність всіх досліджуваних підприємств супроводжена звітом незалежного аудитора про висловлення позитивної чи умовно-позитивної думки про відповідність фінансової звітності даним обліку. Проте результати перевірок контролюючих органів $є$ різними.

Я зазначав В.М. Жук ще в 2007 році «в Україні і до нині відсутня нормативна база щодо сертифікації бухгалтерів, яка передбачає окрім постійного підвищення кваліфікації ще і визначення їх кваліфікаційного рівня та видачу відповідного свідоцтва. Зазначимо, що йдеться про післядипломну освіту бухгалтера. Сертифікат (свідоцтво) видається вже професійному бухгалтеру, 
який після отримання диплому про вищу чи середню спеціальну освіту має практичний досвід роботи. За підходами МФБ сертифікат (свідоцтво) видається не навчальним закладом, а професійною бухгалтерською організацією, після здачі професійним бухгалтером іспитів в незалежній екзаменаційній мережі, що, як правило, контролюється МФБ» [2]. Кожен сертифікат має конкретні вимоги до освіти та досвіду, зосереджується на конкретних навичках, яких необхідно отримати. Існує ціли ряд сертифікатів в залежності від спеціалізації. Нами проаналізовано декілька рейтингів [8; 9] і визначено найбільш поширені в Свропі (табл.8).

Таблиия 8

Чотири найкращі професійні сертифікати з бухгалтерського обліку

\begin{tabular}{|c|c|c|c|c|}
\hline $\begin{array}{c}\text { Показник для } \\
\text { порівняння }\end{array}$ & ACCA & UP & CPA & CFA \\
\hline $\begin{array}{l}\text { Програмний } \\
\text { фокус }\end{array}$ & $\begin{array}{l}\text { Фінансовий } \\
\text { менеджмент, } \\
\text { звітність, } \\
\text { оподаткування, } \\
\text { аудит }\end{array}$ & Управлінський облік & $\begin{array}{l}\text { Фінансовий } \\
\text { менеджмент, } \\
\text { звітність, } \\
\text { оподаткування, } \\
\text { аудит }\end{array}$ & $\begin{array}{l}\text { Управління портфелем, } \\
\text { інвестиції }\end{array}$ \\
\hline $\begin{array}{l}\text { Орієнтовні } \\
\text { витрати }\end{array}$ & Від $2000 \$$ & Від 2000 \$ & Від $1500 \$$ & Від 3700 \$ \\
\hline $\begin{array}{l}\text { Час отримати } \\
\text { сертифікат }\end{array}$ & 3 - 4 роки & 3 - 5 років & $\begin{array}{l}\text { Від } 2,5 \text { років до } 5 \\
\text { років }\end{array}$ & 3 - 5 років \\
\hline $\begin{array}{l}\text { Перспектива } \\
\text { роботи }\end{array}$ & $\begin{array}{l}\text { Банкір, } \\
\text { консультант, } \\
\text { аудитор, } \\
\text { спеціалісти } \\
\text { оподаткування } \\
\text { та права }\end{array}$ & $\begin{array}{l}\text { Бухгалтер } \\
\text { управлінського } \\
\text { обліку, фінансовий } \\
\text { аналітик, фінансовий } \\
\text { менеджер, менеджер з } \\
\text { внутрішнього аудиту }\end{array}$ & $\begin{array}{l}\text { Старший бухгалтер, } \\
\text { менеджер } \\
\text { бухгалтерського } \\
\text { обліку, податковий } \\
\text { менеджер }\end{array}$ & $\begin{array}{lr}\text { Робота } & \text { в } \\
\text { управління } & \text { галузі } \\
\text { прямих } & \text { активами, } \\
\text { досліджень } & \\
\text { акціонерного к капіталу, } \\
\text { інвестиційно- } \\
\text { банківської діяльності }\end{array}$ \\
\hline
\end{tabular}

Джерело: Складено за даними [8; 9]

Як показують дані таблиці, професійна міжнародні сертифікація - це значні витрати для бюджету бухгалтера чи компанії. Зважаючи на переважання мікробізнесу, багатьом роботодавцям послуги сертифікованого бухгалтера будуть занадто дорогими. Практика закордонної сертифікації може бути використана тільки на середніх і великих підприємствах, бюджет яких дозволяє сертифікувати бухгалтера, або виплачувати відповідну заробітну плату для того, щоб бухгалтер міг пройти сертифікацію. Але в цієї групи підприємств аналізований нами показник компетентності $\epsilon$ одним 3 найкращих. Тому якраз у них бухгалтери навчаються і розвиваються. Питання виникають до головних бухгалтерів мікропідприємств, компаній аутсорсінгу. Для цієї групи важливим $€$ пропозиція вітчизняної програми 3 оптимальним бюджетом, проходження якої 3 певною періодичністю стане правилом.

Всі отримані результати дослідження свідчать про важливість сертифікації бухгалтерської професії в Україні

\section{Джерела та література}

1. Бондар М.І., Шигун М.М. Концепція сертифікації бухгалтерів України. Бухгалтерський облік $і$ аудит.

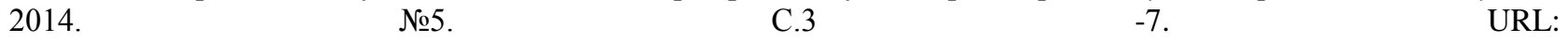
https://core.ac.uk/download/pdf/197270953.pdfhttps://core.ac.uk/download/pdf/197270953.pdf

2. Жук В.М. Сертифікація бухгалтерів: організаційно-методологічні підходи. Облік і фінанси АПК. 2007. № 1-2. C.114-116. URL: http://magazine.faaf.org.ua/sertifikaciya-buhgalteriv-organizaciyno-metodologichnipidhodi.html,

3. Мукан Н., Мукан О., Драган Р. Ппрофесійна підготовка бухгалтера крізь призму потреб роботодавців. Молодь і ринок. 2021. № 2. С.188. 
4. Плікус І., Жукова Т., Осадча С. Модель професії бухгалтер в епоху цифрових трансформацій: ключові напрями компетентностей бухгалтера. Приазовський економічний вісник. 2019. Вип.1 (12). С. $200-205$.

5. Про затвердження Положення про розкриття інформації емітентами цінних паперів НКЦПФР; Рішення Національної комісії цінних паперів та фондового ринку від 03.12.2013 № 2826

6. Рожелюк В. М. Дослідження компетентності професії бухгалтера як фахівця управління бізнес процесами в переробній галузі агропромислового комплексу. Аналітично-інформаційний журнал «Схід». Серія: Економічні науки. 2015. №5 (137). С.81-86

7. Царук Н.Г. "Погляд на кваліфікацію бухгалтера крізь призму запитів роботодавців. Облік $i$ фінанси. 2020 № 87. C. 77-83.

8. Best 4 Professional Certifications for Accounting and Finance Students. URL: https://blog.getunioffer.com/professional-certification-for-finance-and-accounting-students/

9. Bryce Welker. Top 5 Best Accounting Certifications. URL: https://crushthecpaexam.com/best-accountingcertifications/

10. Fereidoon Veisi, Farhad Shahveisi, Farshid Namamyan, Mehrdad Ghanbari. Investigating and identifying effectiv e factors in measuring of meta-competence in accountants. European Journal of Economic and Financial Research. 2019. Volume 3 Issue 4. P.133 151. DOI: http://dx.doi.org/10.46827/ejefr.v0i0.627

11. Setiyawati Hari. The effect of internal accountants' competence, managers' commitment to organizations and the implementation of the internal control system on the quality of financial reporting. International journal of business and management invention 2013. 2.11 . P.19-27.

12. Weiss Fereydun and others. Research and identification of effective factors in measurement of objective competence in accountants. European Journal of Economic and Financial Research. 2019. . Volume 3, Issue 4, DOI: http://dx.doi.org/10.46827/ejefr.v0i0.627

\section{References}

1. Bondar M.I., Shyhun M.M. (2014). Kontseptsiia sertyfikatsii bukhhalteriv Ukrainy [The concept of certification of accountants of Ukraine]. - Bukhhalterskyi oblik $i$ audyt. - Accounting and audit. №5. - P.3-7. URL: https://core.ac.uk/download/pdf/197270953.pdfhttps://core.ac.uk/download/pdf/197270953.pdf [in Ukrainian].

2. Zhuk V.M. (2007). Sertyfikatsiia bukhhalteriv: orhanizatsiino-metodolohichni pidkhody [Certification of accountants: organizational and methodological approaches]. Oblik i finansy APK - Accounting and finance of agroindustrial complex. - № 1-2. - P.114-116. URL: http://magazine.faaf.org.ua/sertifikaciya-buhgalteriv-organizaciynometodologichni-pidhodi.html [in Ukrainian].

3. Mukan N., Mukan O., Drahan R (2021). Pprofesiina pidhotovka bukhhaltera kriz pryzmu potreb robotodavtsiv [Professional training of an accountant through the prism of the needs of employers]. - Molod i rynok-Youth and the market. № 2. - P.188. [in Ukrainian].

4. Plikus I., Zhukova T., Osadcha S. (2019). Model profesii bukhhalter v epokhu tsyfrovykh transformatsii: kliuchovi napriamy kompetentnostei bukhhaltera [Model of the profession of accountant in the era of digital transformations: key areas of competence of the accountant]. - Pryazovskyi ekonomichnyi visnyk- Priazovsky Economic Bulletin. 1 (12). - P. 200-205. [in Ukrainian].

5. Pro zatverdzhennia Polozhennia pro rozkryttia informatsii emitentamy tsinnykh paperiv NKTsPFR; Rishennia Natsionalnoi komisii tsinnykh paperiv ta fondovoho rynku vid 03.12.2013 №2826 [On approval of the Regulations on disclosure of information by issuers of securities by the NSSMC; Decision of the National Commission on Securities and Stock Market dated 03.12.2013 № 2826] [in Ukrainian].

6. Rozheliuk V. M. (2015). Doslidzhennia kompetentnosti profesii bukhhaltera yak fakhivtsia upravlinnia biznes protsesamy v pererobnii haluzi ahropromyslovoho kompleksu [Research of competence of the profession of accountant as a specialist in business process management in the processing industry of the agro-industrial complex]. Analitychno-informatsiinyi zhurnal «Skhid». Seriia: Ekonomichni nauky. - Analytical and information magazine "East". Series: Economic Sciences. №5 (137). - P.81-86. [in Ukrainian].

7. Tsaruk N.H. (2020). Pohliad na kvalifikatsiiu bukhhaltera kriz pryzmu zapytiv robotodavtsiv [A look at the qualifications of an accountant through the prism of employers' inquiries]. - Oblik $i$ finansy-Accounting and finance. № 87. - P. 77-83. [in Ukrainian].

8. Best 4 Professional Certifications for Accounting and Finance Students. URL: https://blog.getunioffer.com/professional-certification-for-finance-and-accounting-students/ 
9. Bryce Welker. Top 5 Best Accounting Certifications. URL: https://crushthecpaexam.com/best-accountingcertifications/

10. Fereidoon Veisi, Farhad Shahveisi, Farshid Namamyan, Mehrdad Ghanbari (2019). Investigating and identifying effectiv e factors in measuring of meta-competence in accountants. - European Journal of Economic and Financial Research. Volume 3 Issue 4. - P.133 151. DOI: http://dx.doi.org/10.46827/ejefr.v0i0.627

11. Setiyawati Hari (2013). The effect of internal accountants' competence, managers' commitment to organizations and the implementation of the internal control system on the quality of financial reporting.- International journal of business and management invention. 2.11. - P.19-27.

12. Weiss Fereydun and others (2019). Research and identification of effective factors in measurement of objective competence in accountants. - European Journal of Economic and Financial Research. Volume 3, Issue 4. DOI: http://dx.doi.org/10.46827/ejefr.v0i0.627

Стаття надійшла до редакції 20.11.2021 р. 